\title{
KEEFEKTIFAN THINK-TALK-WRITE (TTW) TERHADAP KEMAMPUAN KOMUNIKASI MATEMATIS
}

\author{
${ }^{1)}$ Ria Rustian, ${ }^{2)}$ Padrul Jana*, ${ }^{3)}$ Dwi Susilowati \\ ${ }^{1,2,3}$ ) Program Studi Pendidikan Matematika, Universitas PGRI Yogyakarta, Indonesia. \\ *padrul.jana@upy.ac.id
}

\begin{abstract}
Received:

$18 / 05 / 2021$

This study aims to determine the effectiveness of the Think-Talk-Write (TTW) model on the mathematical communication skills of seventh grade students of SMP Negeri 12 Yogvakarta. This tvpe of research is a quasi-experimental studv

Accepted : using a Posttest-Only Control Design. The sample was determined using the 04/06/2021 simple random sampling technique, the experimental class was selected, namely class VII A and the control class namelv class VII B. Class VII A was taught using the Think-Talk-Write (TTW) model and class VII B was taught by direct learning.

Published:

23/06/2021 The instruments used were the learning implementation sheet and the mathematical communication ability test questions. Furthermore, testing the hypothesis using the $t$ test. The results of the research in the experimental class and the control class showed that the results of the midterm assessment (PTS) and the posttest scores of the two classes were normally distributed and had a homogeneous distribution. The results of statistical tests show that learning activities using the Think-Talk-Write (TTW) model are more effective than the direct learning model on the mathematical communication skills of seventh grade students of SMP Negeri 12 Yogyakarta.
\end{abstract}

Kevwords: Effectiveness, Think-Talk-Write, Mathematical Communication Ability.

\begin{abstract}
Abstrak
Penelitian ini bertujuan untuk mengetahui efektivitas model Think-Talk-Write (TTW) terhadap kemampuan komunikasi matematis peserta didik kelas VII SMP Negeri 12 Yogyakarta. Jenis penelitian ini eksperimen semu yang menggunakan desain Posttest-Only Control Design. Penentuan sampel dilakukan dengan teknik Simple Random Sampling, terpilih kelas eksperimen yaitu kelas VII A dan kelas kontrol yaitu kelas VII B. Kelas VII A diajar dengan model Think-Talk-Write (TTW) dan kelas VII B diajar dengan pembelajaran langsung. Instrumen yang digunakan adalah lembar ketelaksanaan pembelajaran dan soal tes emampuan komunikasi matematis. Selanjutnya, pengujian hipoteis menggunakan uji t. Hasil penelitian pada kelas eksperimen dan kelas kontrol menunjukkan bahwa, hasil penilaian tengah semester (PTS) dan nilai posttest kedua kelas berdistribusi normal dan mempunyai sebaran homogen. Hasil uji statistik menunjukan bahwa kegiatan belajar menggunakan model Think-Talk-Write (TTW) lebih efektif dibandingkan model pembelajaran langsung terhadap kemampuan komunikasi matematis peserta didik kelas VII SMP Negeri 12 Yogyakarta.
\end{abstract}

Kata Kunci: Efektivitas, Think-Talk-Write, Kemampuan Komunikasi Matematis

\section{Pendahuluan}

Matematika adalah sebuah ilmu pengetahuan yang dapat mendidik manusia supaya dapat berpikir secara logis, teoritis, rasional, dan sistematis sehingga menjadikan matematika sebagai dasar dalam berkembangnya sebuah ilmu pengetahuan dan teknologi masa kini (Rais \& Yohanes, 2018). Matematika menjadi sebuah ilmu yang dasar memiliki peran serta yang penting dalam mencapai keberhasilan pembangunan di semua bidang (Salim Nahdi, 2019). Pernyataan ini berdasarkan pada dugaan jika penguasaan ilmu matematika dapat dijadikan pedoman kuat dalam belajar ilmu lain, berlaku di tingkat 
pendidikan yang setara atau di tingkat pendidikan yang di atasnya. Matematika adalah pengetahuan umum yang dijadikan pondasi dalam memajukan teknologi masa kini, memiliki fungsi penting di beberapa disiplin dan digunakan untuk mendorong pola berpikir manusia (Ibrahim \& Suparmi, 2009). Salah satu tujuan pembelajaran matematika di Sekolah Menengah Pertama (SMP) adalah mengutarakan ide menggunakan diagram, tabel, simbol atau perantara lainnya yang digunakan untuk menjelaskan suatu situasi yang terjadi (Ibrahim \& Suparmi, 2009).

SMP Negeri 12 Yogyakarta ditemukan permasalahan dalam pembelajaran matematika yang menghambat tercapainya tujuan pembelajaran. Dalam wawancara, guru menyatakan bahwa guru telah menggunakan beberapa metode pembelajaran, diantaranya ceramah (pembelajaran langsung), diskusi dan pemberian tugas. Namun keaktifan peserta didik dalam mengikuti pembelajaran masih belum tampak.

Penemuan yang sama dengan peneltian ini dilakukan oleh Hidayat (Rais \& Yohanes, 2018) memaparkan hasil studi peserta didik yang mendapatkan pembelajaran menggunakan model pembelajaran Mind Mapping, kemampuan komunikasinya lebih baik dibandingkan dengan peserta didik yang mendapatkan pelajaran langsung. Hasil lainnya peserta didik yang pembelajarannya dengan model Mind Mapping mempunyai keahlian menduga, mengkaji, dan membuat kesimpulan yang berkembang dengan baik dibandingkan peserta didik yang belajar dengan pembelajaran langsung.

Aspek yang terdapat dalam pembelajaran matematika salah satunya yaitu komunikasi (Andini et al., 2019). Komunikasi mempunyai fungsi yang penting untuk menolong peserta didik tidak hanya dalam membentuk konsep namun membentuk hubungan antara ide dan bahasa abstrak dengan simbol matematika (Astuti \& Leonard, 2012). Kemampuan komunikasi matematis merupakan keahlian untuk mengutarakan suatu ide pikiran atau gagasan matematis, melalui tulisan maupun lisan, keahlian dalam mengartikan serta memperolah ide matematis yang berasal dari pihak lain dengan analitik, cermat, evaluative, dan kritis untuk menambah pengetahuan (Lestari, K. E. \& Yudhanegara, 2015). Kemampuan komunikasi matematis merupakan keahlian yang dipunyai peserta didik dalam memaparkan masalah atau ide di dalam pembelajaran matematika dengan menggunakan benda yang konkret, grafik, gambar, atau tabel, dan simbol-simbol matematika (Astuti \& Leonard, 2012). Senada dengan Astuti dan Leonard, menurut (Damayanti et al., 2020) menyatakan bahwa kemampuan komunikasi matematis adalah kemampuan yang dibutuhkan dalam mempelajari ilmu matematika untuk 
mempelajari konsep, menyampaikan atau mengungkapkan gagasan-gagasan secara tulisan ataupun lisan dalam bentuk gambar, diagram, simbol, dan penggunaan objek. Sehingga kemampuan komunikasi matematis suatu hal yang dibutuhkan di dalam mempelajari ilmu matematika. Dari beberapa pemaparan maka dapat diambil kesimpulan jika kemampuan komunikasi matematis adalah kemampuan untuk menyampaikan suatu ide matematik melalui lisan maupun tertulis yang terjadi di dalam kelas.

Kurangnya kemampuan komunikasi matematis peserta didik terlihat ketika peserta didik menghadapi soal matematika dan dalam berkomunikasi di kelompok belajar (Damayanti et al., 2020). Peserta didik mengalami kesulitan dalam berkomunikasi di kelompok, kurang beraninya peserta didik untuk menyampaikan gagasan atau ide yang dimiliki (Hayati et al., 2016). Peserta didik dalam menyelesaikan soal-soal pada kegiatan belajar terlihat kurang aktif. Peserta didik hanya menerima secara pasif dan terkadang peserta didik tidak memperhatikan apa yang disampaikan guru dengan hanya mencatat penjelasan dari guru, sehingga mengakibatkan kurangnya pemahaman peserta didik terhadap materi pembelajaran. Peneliti juga melakukan tes untuk melihat kemampuan matematis peserta didik kelas VII dengan memberikan tes uraian dengan indikator untuk mengukur kemampuan komunikasi diantaranya: 1) menghubungkan benda-benda konkret, diagram dan gambar kedalam gagasan matematika, 2) menjelaskan gagasan, keadaan, dan hubungan matematika melalui tulisan atau lisan, dengan benda konkret, grafik, aljabar, dan gambar, 3) menyatakan situasi yang terjadi di kehidupan sehari-hari kedalam bahasa matematika. Hasil tes diperoleh dengan nilai pada tabel 1 berikut:

Tabel 1. Nilai Rata-rata Tes Kemampuan Komunikasi Peserta didik

\begin{tabular}{ll}
\hline Indikator & Nilai \\
\hline $\begin{array}{l}\text { menghubungkan benda-benda konkret, diagram dan } \\
\text { gambar kedalam gagasan matematika, }\end{array}$ & 44.25 \\
menjelaskan gagasan, keadaan, dan hubungan & \\
matematika melalui tulisan atau lisan, dengan benda & 49.75 \\
$\begin{array}{l}\text { konkret, grafik, aljabar, dan gambar } \\
\text { menyatakan situasi yang terjadi di kehidupan }\end{array}$ & 47.8 \\
$\begin{array}{l}\text { sehari-hari kedalam bahasa matematika } \\
\end{array}$
\end{tabular}

Dari hasil nilai rata-rata pada tabel 1 menunjukkan jika kemampuan komunikasi matematis peserta didik kelas VII SMP Negeri 12 Yogyakarta dalam kategori rendah. Peserta didik kurang aktif dalam pembelajaran sedangkan guru lebih banyak berperan dalam pembelajaran (Jumrawarsi \& Suhaili, 2020). Pembelajaran cenderung berpusat kepada guru sehingga menjadikan kemampuan komunikasi matematis peserta didik 
kurang. Mengetahui pentingnya komunikasi, tidak datang dengan sendirinya tanpa perantara suatu cara yaitu dengan model pembelajaran sebagai suatu cara untuk mencapai tujuan (Lestari Bandi et al., 2015). Model pembelajaran yang dapat digunakan yaitu pembelajaran dengan berbasis masalah, hal ini dikarena penggunaan model berbasis masalah dianggap mampu menuntun peserta didik dalam memainkan perannya untuk menggali kemampuan komunikasi matematis yang dipunyai dan diterima lewat pembelajaran matematika, karena di model pembelajaran tersebut yaitu mengedepankan permasalahan yang konkret (Lestari Bandi et al., 2015). Model pembelajaran dengan berbasis masalah yang mampu memberikan pengaruh terhadap kemampuan komunikasi matematis adalah model Think-Talk-Write (TTW) (Kuslinar et al., 2019). Seperti penelitian yang sudah dilakukan Lusia Ari Sumirat memperlihatkan jika penggunaan model Think-Talk-Write (TTW) lebih efektif digunakan untuk mengasah kemampuan komunikasi serta diposisi matematis peserta didik daripada menggunakan pembelajaran langsung tipe ekspositori (Lusi Ari Sumirat, 2014).

Think-Talk-Write (TTW) merupakan bagian dari model pembelajaran kooperatif yang mengutamakan proses pembelajaran menyusun, berpikir, merefleksikan, menguji, dan menuliskan gagasan-gagasan (Lestari, K. ., \& Yudhanegara, 2015; Pratiwi \& Lidinillah, 2016; Supandi et al., 2018). Pada pendekatan pembelajaran aktif ini peserta didik diinginkan mampu mengembangkan kemampuan komunikasi matematis saat kegiatan pembelajaran. Peserta didik yang mempunyai kemampuan komunikasi matematis tinggi mampu mengutarakan gagasan matematis, secara tulisan maupun lisan dan memiliki kemampuan mengartikan serta menerima ide matematis dari pihak lain dengan cermat, analitik, evaluatif, dan kritis sehingga menambah pemahaman (Lestari, K. ., \& Yudhanegara, 2015).

Model Pembelajaran Think-Talk-Write (TTW) yaitu mengutamakan pentingnya peserta didik mengungkapkan apa yang menjadi ide mengenai permasalahan yang berasal dari guru. Aspek lain yang memperlihatkan keterkaitan model Think-Talk-Write (TTW) dengan kemampuan komunikasi matematis yaitu diskusi dan menulis (Nurapriani, 2016). Bagian dari komunikasi yang lain, bahwa suatu kegiatan belajar dapat menuntun peserta didik dalam mengutarakan gagasan matematis melalui mendengar, presentasi, berdiskusi, membaca, dan menulis. Penerapan model Think-Talk-Write (TTW) berakibat peserta didik yang tadinya pasif berubah menjadi aktif dalam melaksanakan proses pembelajaran. 
Berdasarkan paparan tersebut penelitian dengan mengujicobakan model Think-TalkWrite (TTW) terhadap kemampuan komunikasi matematis menjadi penting.

\section{Metode}

Populasi yang digunakan dalam penelitian yaitu peserta didik kelas VII SMP Negeri 12 Yogyakarta yang terbagi menjadi lima kelas. Semua Kelas VII di SMP Negeri 12 Yogyakarta merupakan kelas homogen dikarenakan peserta didik memperoleh bahan pembelajaran berdasarkan kurikulum yang sama dan dalam pembagian kelas tidak ada kelas peserta didik unggul, semua peserta didik memiliki kemampuan sama. Dikarenakan semua kelas homogen penentuan sampel menerapkan teknik Simple Random Sampling menggunakan cara pengundian. Terpilih kelas eksperimen yaitu kelas VII A dan kelas kontrol yaitu kelas VII B. Kedua kelas merupakan kelas homogen.

Tabel 2. Hasil Uji Homogenitas Nilai PTS Kelas VII A dan Kelas VII B

\begin{tabular}{llcccc}
\hline & & Levene Statistic & df1 & df2 & Sig. \\
\hline \multirow{3}{*}{ Mid - test } & Based on Mean & 1.321 & 1 & 64 & .255 \\
\cline { 2 - 6 } & Based on Median & .727 & 1 & 64 & .387 \\
\cline { 2 - 6 } & $\begin{array}{l}\text { Based on Median } \\
\text { and with adjusted df }\end{array}$ & .727 & 1 & $\begin{array}{c}61.07 \\
2\end{array}$ & .397 \\
\cline { 2 - 6 } & $\begin{array}{l}\text { Based on trimmed } \\
\text { mean }\end{array}$ & 1.118 & 1 & 64 & .294 \\
\hline
\end{tabular}

Pada based on means diperoleh 1,321. Dapat dilihat bahwa 1,321>0.05 sehingga nilai PTS tersebut homogen. Penelitian ini kelas eksperimen memperoleh perlakuan dengan model Think-Talk-Write (TTW) dan kelas kontrol menggunakan pembelajaran langsung. Sesudah memperoleh perlakuan kedua kelas diberikan tes akhir yang bertujuan melihat hasil belajarnya.

Model Think-Talk-Write (TTW) di penelitian berperan sebagai variabel bebas dan kemampuan komunikasi matematis berperan sebagai variabel terikat. Penggunaan tes, observasi, dan dokumentasi digunakan untuk mengumpulan data-data dalam penelitian. Dari hasil analisis data nilai Penilaian Tengah Semester (PTS) didapatkan populasi di penelitian berdistribusi normal dan mempunyai varians yang homogen. Pada akhir penelitian di kedua kelas yang dijadikan sampel penelitian diberikan tes yang bertujuan mendapatkan data tes kemampuan komunikasi matematis. Selanjutnya data hasil tes di uji menggunakan uji t untuk melihat keefektivannya dengan kriteria apabila nilai sig < alpha maka pembelajaran menggunakan model Think-Talk-Write (TTW) lebih efektif dari model pembelajaran langsung. 


\section{Hasil Dan Pembahasan}

\section{Deskripsi Data}

Data yang diperoleh dalam penelitian ini terdiri dari nilai posttest siswa kelas eksperimen yang mendapatkan perlakuan model pembelajaran kooperatif tipe Think-Talk-Write (TTW) dan siswa kelas kontrol yang mendapat perlakuan pembelajaran langsung. Kelas eksperimen jumlah siswa yang mengikuti posttest sebanyak 28 siswa dan di kelas kontrol jumlah siswa yang mengikuti posttest sebanyak 25 siswa. Hasil posttest digunakan untuk mengukur seberapa besar kemampuan komunikasi matematis siswa setelah diberi perlakukan pembelajaran. Berikut merupakan tabel deskripsi hasil kemampuan komunikasi matematis kelas eksperiman dan kelas kontrol.

Tabel 3. Hasil Tes Kemampuan Komunikasi Matematis Peserta didik

\begin{tabular}{ccc}
\hline Indikator Kemampuan & \multicolumn{2}{c}{ Pencapaian Tiap Indikator Soal } \\
\cline { 2 - 3 } Komunikasi Matematis & Kelas Eksperimen & Kelas Kontrol \\
\hline A & 79,17 & 76,8 \\
B & 74,83 & 74,19 \\
C & 63,09 & 62,22 \\
D & 73,66 & 53 \\
Rata-rata & 72,69 & 66,55 \\
Kriteria & Baik & Baik \\
Nilai Tertinggi & 82 & 80 \\
Nilai Terendah & 61 & 55 \\
\hline
\end{tabular}

Keterangan Indikator Kemampuan Komunikasi Matematis :

A: Menghubungkan benda nyata, gambar, dan diagram ke dalam ide matematika.

B: Menjelaskan ide, situasi, dan relasi matematika secara lisan atau tulisan, dengan benda nyata, gambar, grafik, dan aljabar.

C: Menyatakan peristiwa sehari-hari dalam bahasa matematika.

D: Membuat konjektur, menyusun argumen, merumuskan definisi dan generalisasi.

\section{Analisis Instrumen}

Instrumen tes diuji coba pada 31 siswa di kelas VIII D yang sebelumnya telah mendapatkan materi persegi di kelas VII. Hasil uji coba diuji validitas menggunakan rumus koefisien korelasi product moment pearson sebagai berikut: 
Tabel 4. Hasil Validitas Soal

\begin{tabular}{cccccccc}
\hline & \multicolumn{7}{c}{ Butir Soal } \\
\cline { 2 - 8 } Pearson & 1 & 2 & 3 & 4 & 5 & 6 & 7 \\
\cline { 2 - 7 } Correlation & 0,666 & 0,486 & 0,796 & 0,679 & 0,497 & 0,668 & 0,777 \\
Kesimpulan & Valid & Valid & Valid & Valid & Valid & Valid & Valid \\
\hline Sedangkan hasil dari uji & reliabilitas & menggunakan uji & Cronbach-alpha yaitu
\end{tabular}
sebagai berikut:

Tabel 5. Hasil Reliabilitas Soal

\begin{tabular}{cc}
\hline Cronbach's Alpha & N of Items \\
\hline 0,762 & 7 \\
Kesimpulan & Reliabel \\
\hline
\end{tabular}

\section{Analisis Lembar Observasi Keterlaksanaan Pembelajaran}

Hasil observasi diperoleh menggunakan pedoman lembar observasi yang dilakukan observer. Observasi ini digunakan untuk mengetahui keterlaksanaan pembelajaran pada kelas eksperimen maupun kelas kontrol. Pada kelas eksperimen yaitu untuk mengetahui keterlaksanaan pembelajaran dengan menggunakan model pembelajaran koperatif tipe Think-Talk-Write (TTW). Kemudian, kelas kontrol untuk mengetahui keterlaksanaan pembelajaran dengan menggunakan model pembelajaran langsung. Dalam observasi yang menjadi responden adalah guru dan siswa. Hasil dari observasi guru dan siswa dapat ditunjukkan sebagai berikut:

Tabel 6. Hasil Observasi Keterlaksanaan Pembelajaran Guru dan Siswa

\begin{tabular}{|c|c|c|c|c|}
\hline \multirow[b]{3}{*}{ Pertemuan ke-1 } & \multicolumn{2}{|c|}{ Kelas Eksperimen } & \multicolumn{2}{|c|}{ Kelas Kontrol } \\
\hline & Guru & Siswa & Guru & Siswa \\
\hline & $93,75 \%$ & $86,36 \%$ & $94,12 \%$ & $90,48 \%$ \\
\hline Pertemuan ke-2 & $100 \%$ & $90,91 \%$ & $94,44 \%$ & $90,48 \%$ \\
\hline Rata-rata & $96,87 \%$ & $88,63 \%$ & $94,28 \%$ & $90,48 \%$ \\
\hline Kriteria & Sangat Baik & Sangat Baik & Sangat Baik & Sangat Baik \\
\hline
\end{tabular}

\section{Lembar Observasi Kemampuan Komunikasi Matematis}

Hasil observasi diperoleh dengan menggunakan pedoman lembar observasi yang dilakukan guru. Observasi ini digunakan untuk mengetahui kemampuan komunikasi matematis yang dapat dinilai dengan observasi pada kelas eksperimen maupun kelas kontrol. Dalam observasi yang menjadi responden adalah siswa. Observasi dilakukan selama kegiatan pembelajaran berlangsung. Hasil dari observasi siswa dapat ditunjukkan sebagai berikut: 
Tabel 7. Hasil Observasi Kemampuan Komunikasi Matematis

\begin{tabular}{cccc}
\hline \multirow{2}{*}{ Sikap/Nilai } & Keterangan & $\begin{array}{c}\text { Kelas } \\
\text { Eksperimen } \\
\text { (VII A) }\end{array}$ & $\begin{array}{c}\text { Kelas } \\
\text { Kontrol } \\
\text { (VII B) }\end{array}$ \\
\hline \multirow{2}{*}{ Keaktifan } & Kurang Baik & $23,53 \%$ & $31,25 \%$ \\
Diskusi & Baik & $47,06 \%$ & $43,75 \%$ \\
& Sangat Baik & $29,41 \%$ & $25 \%$ \\
Kelancaran & Kurang Baik & $35,29 \%$ & $40,62 \%$ \\
Membaca & Baik & $29,41 \%$ & $46,87 \%$ \\
& Sangat Baik & $35,29 \%$ & $12,5 \%$ \\
Keaktifan & Kurang Baik & $44,12 \%$ & $50 \%$ \\
bertanya & Baik & $35,29 \%$ & $34,37 \%$ \\
& Sangat Baik & $20,59 \%$ & $15,62 \%$ \\
\hline
\end{tabular}

\section{Analisis Uji Prasyarat}

Uji normalitas digunakan untuk mengetahui apakah hasil kemampuan komunikasi matematis siswa kelas eksperimen dan kelas kontrol dari populasi yang berdistribusi normal atau tidak. Pengujian uji normalitas menggunakan uji Kolmogorov Smirnov. Adapun hasilnya tersaji dalam tabel 8 di bawah ini:

Tabel 8. Hasil Uji Normalitas Nilai Kelas Eksperimen dan Kontrol

\begin{tabular}{lcccl}
\hline \multirow{2}{*}{ Kelas } & \multicolumn{3}{c}{ Kolmogorov-Smirnov" } & \multirow{2}{*}{ Kesimpulan } \\
\cline { 2 - 4 } & Statistic & df & Sig. & \\
\hline Eksperimen & 0,146 & 28 & 0,131 & Berdistribusi \\
Kontrol & 0,159 & 28 & 0,101 & Normal
\end{tabular}

Uji homogenitas digunakan untuk mengetahui apakah variansi pada kelas eksperimen dan kelas kontrol berasal dari sampel yang homogen atau tidak. Adapun hasilnya tersaji dalam Tabel 9:

Tabel 9. Hasil Uji Homogenitas

\begin{tabular}{|c|c|c|c|c|c|}
\hline & & $\begin{array}{l}\text { Levene } \\
\text { Statistic }\end{array}$ & df1 & df 2 & Sig. \\
\hline & $\begin{array}{l}\text { Based on } \\
\text { Mean }\end{array}$ & 0,259 & 1 & 51 & 0,613 \\
\hline $\begin{array}{l}\text { Homogenitas } \\
\text { Posttest } \\
\text { Kelas }\end{array}$ & $\begin{array}{l}\text { Based on } \\
\text { Median }\end{array}$ & 0,139 & 1 & 51 & 0,711 \\
\hline $\begin{array}{l}\text { Eksperimen } \\
\text { dan Kelas } \\
\text { Kontrol }\end{array}$ & $\begin{array}{l}\text { Based on } \\
\text { Median and } \\
\text { with } \\
\text { adjusted df }\end{array}$ & 0,139 & 1 & 50,768 & 0,711 \\
\hline
\end{tabular}




\begin{tabular}{llllll}
\hline & $\begin{array}{c}\text { Levene } \\
\text { Statistic }\end{array}$ & df1 & df2 & Sig. \\
\hline $\begin{array}{l}\text { Based on } \\
\text { trimmed } \\
\text { mean }\end{array}$ & 0,221 & 1 & 51 & 0,640 \\
\hline
\end{tabular}

Berdasarkan Tabel 9 nilai based on mean diperoleh nilai sig. $=0,613 \geq \alpha(0,05)$ maka $\mathrm{H}_{0}$ diterima, artinya data nilai siswa pada kelas eksperimen dan kelas kontrol mempunyai variansi yang sama (homogen).

\section{Pengujian Hipotesis}

Kriteria yang ditetapkan pada kemampuan komunikasi matematis adalah nilai rata-rata peserta didik lebih dari 70 atau kemampuan komunikasi matematis dengan kriteria baik. Untuk menguji hipotesis 1 dan hipotesis 2 digunakan uji t satu sampel. Hasil hipotesis 1 didapatkan hasil nilai sig. $=0,000 \leq \alpha=0,05$. Hasil ini memperlihatkan jika model Think-Talk-Write (TTW) efektif digunakan dilihat dari kemampuan komunikasi matematis. Selanjutnya hipotesis 2 didapatkan hasil nilai sig. $=0,0495 \leq \alpha=0,05$ artinya bahwa model pembelajaran langsung efektif di pembelajaran matematika dilihat dari kemampuan komunikasi matematis. Sedangkan hasil hipotesis 3 dengan menggunakan uji t dua sampel diperoleh nilai sig. $=0,040 \leq \alpha=0,05$. Sehingga diperoleh jika model Think-Talk-Write (TTW) lebih efektif daripada model pembelajaran langsung dilihat dari kemampuan komunikasi matematis.

\section{Kesimpulan}

Model Think-Talk-Write (TTW) sudah memenuhi kriteria ketuntasan minimal yang ditetapkan yaitu rata-rata nilai tes kemampuan komunikasi matematis peserta didik lebih dari 70. Perolehan nilai tes kemampuan komunikasi matematis peserta didik yang mendapatkan perlakukan dengan model Think-Talk-Write (TTW) terlihat lebih efektif dibandingkan nilai tes kemampuan komunikasi matematis yang mendapatkan perlakukan pembelajaran langsung. Hasil yang didapatkan yaitu model Think-Talk-Write (TTW) lebih efektif daripada model pembelajaran langsung di kelas VII SMP Negeri 12 Yogyakarta.

\section{Pustaka}

Andini, D., Mulyani, N., Wijaya, T. T., \& Supriyati, D. N. (2019). Meningkatkan Kemampuan Komunikasi Matematis Dan Self Confidence Siswa Menggunakan Pendekatan PBL Berbantuan Geogebra. Jurnal Derivat: Jurnal Matematika Dan Pendidikan Matematika, 5(1), 82-93. https://doi.org/10.31316/j.derivat.v5i1.150

Astuti, A., \& Leonard. (2012). Peran Kemampuan Komunikasi Matematika Terhadap Prestasi Belajar Matematika Peserta Didik. Jurnal Formatif, 102-110. 
Damayanti, R. R., Zulkarnain, I., \& Sari, A. (2020). Kemampuan Komunikasi Matematis Siswa Dalam Pembelajaran Matematika Menggunakan Model Quick on the Draw. EDU-MAT: Jurnal Pendidikan Matematika, 8(1), 54-61. https://doi.org/10.20527/edumat.v8i1.8352

Hayati, S., Yani, A., \& Waluya, B. (2016). Penggunaan Media Komik Tanpa Kata Untuk Meningkatkan Keberanian Mengemukakan Pendapat Pada Mata Pelajaran Geografi Di Smpn 12 Bandung. Jurnal Geografi Gea, 6(2). https://doi.org/10.17509/gea.v6i2.1740

Ibrahim, \& Suparmi. (2009). Strategi Pembelajaran Metematika. Teras.

Jumrawarsi, \& Suhaili, N. (2020). Peran Seorang Guru Dalam Menciptakan Lingkungan Belajar Yang Kondusif. Ensiklopedia Education Review, 2(3), 50-54. https://doi.org/https://doi.org/10.33559/eer.v2i3.628

Kuslinar, K., Awaludin, A., \& La Arapu, L. A. (2019). Pengaruh Model Pembelajaran Kooperatif Tipe Think Talk Write (Ttw) Terhadap Kemampuan Komunikasi Matematis Siswa Kelas Viii Smp Negeri 1 Sampara. Jurnal Penelitian Pendidikan Matematika, 7(1), 141. https://doi.org/10.36709/jppm.v7i1.8255

Lestari, K. ., \& Yudhanegara, M. (2015). Penelitian Pendidikan Matematika. Refika Aditama.

Lestari, K. E., \& Yudhanegara, M. R. (2015). Penelitian Pendidikan Matematika. PT Refika Aditama.

Lestari Bandi, N. T. L., Hasnawati, \& Ikman. (2015). Pengaruh Model Pembelajaran Berbasis Masalah Terhadap Hasil Belajar Matematika Siswa Kelas VIII SMP Negeri 12 Kendari. Jurnal Penelitian Pendidikan Matematika, 3(3), 69-82. https://doi.org/http://dx.doi.org/10.36709/jppm.v3i3.3022

Lusi Ari Sumirat. (2014). Issn: 2356-3915 21. Efektifitas Strategi Pembelajaran Kooperatif Tipe Think-Talk-Write (TTW) Terhadap Kemampuan Komunikasi Dan Disposisi Matematis Siswa, 1(2), 24.

Nurapriani, F. (2016). Meningkatkan Kemampuan Komunikasi Dan Koneksi Matematik Siswa Smp Melalui Strategi Think Talk Write. Buana Ilmu, 1(1), 45-55. https://doi.org/10.36805/bi.v1i1.97

Pratiwi, V., \& Lidinillah, D. A. M. (2016). Think-talk-write Strategy to Develop Fifth Grade Students' Mathematical Communication Ability in Comparison. Education in the 21th Century: Responding to Current Issues Think-Talk-Write, 926-936. http://pasca.um.ac.id/conferences/index.php/ice/article/view/124/119

Rais, H., \& Yohanes. (2018). Eksperimentasi Model Pembelajaran Mind Mapping terhadap Kemampuan Komunikasi Matematis Ditinjau dari Motivasi Belajar Peserta Didik Kelas VIII MTs Negeri Bangko. Edumatica, 36-48.

Salim Nahdi, D. (2019). Keterampilan Matematika Di Abad 21. Jurnal Cakrawala Pendas, 5(2), 133-140. https://doi.org/10.31949/jcp.v5i2.1386

Supandi, S., Waluya, S. B., Rochmad, R., Suyitno, H., \& Dewi, K. (2018). Think-talkwrite model for improving students' abilities in mathematical representation. International Journal of Instruction, 11(3), 77-90. https://doi.org/10.12973/iji.2018.1136a 